El-Ibtidaiy: Journal of Primary Education p-ISSN:2620-3251 | e-ISSN: 2615-6121 Vol. 2, No. 1, April 2019, Hal 18-31

\title{
Penerapan Model Pembelajaran Science, Technology and Society untuk Meningkatkan Keterampilan Proses Peserta Didik pada Mata Pelajaran Ilmu Pengetahuan Alam di Kelas IV Madrasah Ibtidaiyah Al-Hanin Kecamatan Tualang Kabupaten Siak
}

\author{
Arinta Indah Ramadhani ${ }^{1}$, Herlina ${ }^{2}$, Theresia Lidya Nova ${ }^{3}$ \\ ${ }^{1,2,3}$ Program Studi Pendidikan Guru Madrasab Ibtidaiyah, Universitas Islam Negeri Sultan Syarif Kasim Riau \\ e-mail: arintaindah1297@gmail.com
}

\begin{abstract}
This research aimed at increasing student process skill on Natural Science subject through Science, Technology, and Society learning model at the fourth grade of Islamic Elementary School of Al-Hanin Tualang District, Siak Regency. It was instigated by the low of student process skill, it could be seen from 2 of 12 students who showed their process skill on good category because they could observe, communicate, classify, measure, predict, and conclude well. It was a Classroom Action Research. The subjects of this research were a teacher and 12 students. Observation, interview, and documentation were the techniques of collecting the data. Analyzing the data was using Descriptive analysis with percentage. Based on the research findings and data analyses, it showed that process skill before the action was $47.08 \%$ and it was on poor category. After being implemented Science, Technology, and Society learning model in the first cycle, student process skill was $65.95 \%$ and it was on enough category. In the second cycle, student process skill increased to classically and $82.80 \%$ individually. It meant that it had achieved the successful indicator that was determined. Therefore, it could be concluded that the implementation of Science, Technology, and Society learning model could increase process skill..
\end{abstract}

Keywords: Process Skill, Science Technology and Society Learning Model, Natural Science

\section{PENDAHULUAN}

Seorang psikolog pendidikan asal Amerika Serikat yang bernama Benjamin Bloom mencetuskan istilah taksonomi bloom yang membahas tentang tiga ranah tujuan pendidikan, yaitu: ranah kognitif, ranah afektif, dan ranah psikomotor (Mardia Hayati dan Nurhasnawati, 2014: 49). Bloom berpendapat, bahwa dalam proses pembelajaran, ketiga ranah tersebut harus saling berkesinambungan. Namun, pada kenyataannya masih banyak aktivis pendidikan yang hanya menggali sisi kognitif peserta didik sehingga ranah psikomotor atau keterampilan sering terabaikan. Menurut Abruscato, pembelajaran sains secara spesifik bertujuan untuk mengembangkan pengetahuan, sikap dan keterampilan. Salah satu keterampilan yang penting dalam pembelajaran Ilmu Pengetahuan Alam (IPA) adalah keterampilan proses (Susilawati, 2014: 114).

Keterampilan proses merupakan keseluruhan keterampilan ilmiah yang terarah (baik kognitif maupun psikomotor) yang dapat digunakan untuk menemukan suatu konsep atau prinsip atau teori, untuk mengembangkan konsep yang telah ada sebelumnya, ataupun 
untuk melakukan penyangkalan terhadap suatu penemuan. Dengan kata lain keterampilan ini dapat digunakan sebagai wahana penemuan dan pengembangan konsep/prinsip atau teori.

Suatu studi iluminatif yang dilakukan oleh Dahar tentang kesiapan guru mengajar di sekolah dasar ditinjau dari segi pengembangan keterampilan proses sains ditemukan hasil bahwa rendahnya keterampilan proses sains peserta didik karena metode atau teknik yang digunakan guru. Kesiapan guru mengajar sangat berpotensi dalam mempengaruhi proses pembelajaran sains. Hal senada juga diungkapkan oleh Rohmat yang melakukan penelitian tentang pelatihan guru sekolah dasar model simulasi untuk meningkatkan pembelajaran sains. Dari penelitian tersebut ditemukan bahwa sebagian besar guru belum terbiasa mengembangkan aspek-aspek keterampilan proses sains dalam menyusun perencanaan maupun pelaksanaan pembelajaran sains. Kondisi tersebut berdampak pada keterampilan proses (Susilawati, 2014: 116).

Pada pembelajaran materi sumber bunyi yang diajarkan pada peserta didik di kelas IV Madrasah Ibtidaiyah Al-Hanin terdapat 2 peserta didik (16,66\%) menunjukkan keterampilan proses pada kategori tinggi, 4 peserta didik $(33,33 \%)$ berada pada kategori sedang, dan 6 peserta didik $(50 \%)$ berada pada kategori rendah. Data menunjukan bahwa keterampilan proses peserta didik masih tergolong rendah karena belum mampu mencapai $80 \%$ dari indikator keberhasilan yang telah ditetapkan.

Berkaitan dengan hasil temuan di atas keterampilan proses pada pembelajaran IPA tersebut harus ada usaha yang dilakukan untuk meningkatkan keterampilan proses peserta didik. Oleh karena itu penulis mencoba menerapkan penelitian tindakan kelas menggunakan model pembelajaran Science, Technology and Society atau STS dimana model pembelajaran ini memadukan pemahaman dan pemanfaatan sains, teknologi, dan masyarakat dengan tujuan agar konsep sains dapat diaplikasikan melalui keterampilan yang bermanfaat bagi peserta didik dan masyarakat. Kaitan antara keterampilan proses dan model pembelajaran STS begitu erat. Keterampilan proses menuntut peserta didik ikut berperan aktif dalam pembelajaran, mendorong peserta didik untuk berpikir kritis sesuai dengan masalah yang sedang dihadapi dan menyelesaikan permasalahan dengan prosedurprosedur atau langkah-langkah tertentu. Sedangkan model pembelajaran STS merupakan model pembelajaran yang mengajak peserta didik untuk kritis atas masalah-masalah yang sedang hangat di dalam kehidupan masyarakat, masalah ini kemudian diamati dan dicari jalan keluarnya menggunakan langkah-langkah ilmiah. Dengan sendirinya pembelajaran ini juga mendorong keterampilan proses peserta didik terhadap konsep yang ada, serta memberikan solusi yang tepat terhadap isu-isu yang berkembang pada masyarakat.

\section{METODOLOGI}

Bentuk dari penelitian ini adalah penelitian tindakan kelas (PTK). Arikunto (2002:104) mengemukakan bahwa penelitian tindak kelas adalah penelitian yang akar permasalahnya muncul di dalam kelas, dan dirasakan langsung oleh guru yang bersangkutan sehingga sulit dibenarkan jika ada anggapan bahwa permasalahn dalam penelitian tindakan kelas diperoleh dari presepsi peneliti semata. Penelitian tindakan kelas ini menerapkan model pembelajaran STS untuk meningkatkan keterampilan proses peserta didik di kelas IV Madrasah Ibtdaiyah Al-Hanin Kecamatan Tualang Kabupaten Siak pada subtema 5 Pahlawanku pada pembelajaran IPA materi sifat cahaya pada bulan 
Januari tahun 2019. Subjek dalam penelitian ini adalah peserta didik di kelas IV yang sebanyak 12 orang, 8 orang peserta didik perempuan dan 4 orang peserta didik laki-laki.

Prosedur PTK ini terdiri dari empat tahapan yang saling terkait dan berkesinambungan, yaitu perencanaan, tindakan, observasi, dan refleksi. PTK tersebut adalah: 1) penyusunan instrumen dilakukan minggu ke-3 dan 4 bulan Desember tahun 2018, 2) pelaksanaan pembelajaran siklus 1 dilakukan pada minggu ke-2 bulan Januari tahun 2019, 4) pembelajaran siklus 2 dilaksanakan minggu ke-3 bulan Januari tahun 2019. Penentuan jadwal ini disesuaikan dengan urutan kompetensi dasar pada silabus dan kalender pendidikan.

Teknik pengumpulan data dalam penelitian ini menggunakan observasi, dokumentasi dan wawancara. Pelaksanaan observasi dilakukan oleh observer dengan menggunakan lembar observasi yang mengacu pada pemberian tugas berupa membuat percobaan yang berhubungan dengan sifat-sifat cahaya. Dokumentasi berupa foto dan video saat melakukan penelitian sebagai instrumen pendukung. Penelitian ini dikatakan berhasil apabila $80 \%$ peserta didik telah mampu untuk melaksanakan indikator keterampilan proses yang sudah ditetapkan yakni mengamati, mengkomunikasikan, mengelompokkan, mengukur, memprediksikan dan menyimpulkan.

Pengolaan data dalam penelitian ini dilakukan dengan menggunakan analisis deskriptif. Data yang diperoleh dalam penelitian ini adalah data observasi aktivitas guru dan peserta didik serta keterampilan proses. Data tersebut diolah dengan menggunakan rumus persentase, yaitu sebagai berikut:

$$
P=\frac{F}{N} x 100
$$

Keterangan:

$$
\begin{array}{ll}
\mathrm{P} & =\text { Angka persentase aktvitas guru/peserta didik } \\
\mathrm{F} & =\text { Frekuensi aktvitas guru } \\
\mathrm{N} & =\text { Jumlah indikator } \\
100 \% & =\text { Bilangan tetap }
\end{array}
$$

Menurut Suharsimi Arikunto, dalam menentukan kriteria penilaian tentang aktivitas guru dan aktivitas peserta didik, maka dilakukan pengelompokkan atas 4 kriteria penilaian yaitu sebagai berikut:

Tabel 1. Hasil Pengamatan Aktivitas Guru dan Aktivitas Peserta Didik

\begin{tabular}{lllll}
\hline No & \multicolumn{2}{c}{ Aktivitas Guru } & \multicolumn{2}{l}{ Aktivitas peserta didik } \\
& Interval & Kategori & Interval & Kategori \\
\hline 1 & $81-100 \%$ & Baik & $76-100 \%$ & Tinggi \\
2 & $61-80 \%$ & Cukup Baik & $56-75 \%$ & Cukup Tinggi \\
3 & $41-60 \%$ & Kurang Baik & $41-55 \%$ & Kurang Baik \\
4 & $0-40 \%$ & Tidak Baik & $\leq 40 \%$ & Tidak Baik \\
\hline
\end{tabular}


Menafsirkan persentase berdasarkan kriteria yang dikemukakan oleh Ngalim Purwanto, Menurut Ngalim Purwanto, dalam menentukan kriteria penilaian tentang keterampilan proses maka dilakukan pengelompokkan atas 5 kriteria penilaian yaitu sebagai berikut:

Tabel 2. Interval Kriteria Penilaian Keterampilan Proses

\begin{tabular}{lll}
\hline No & Interval & Kategori \\
\hline 1 & $\leq 54 \%$ & Kurang sekali \\
2 & $55-59 \%$ & Kurang \\
3 & $60-75 \%$ & Cukup \\
4 & $76-85 \%$ & Baik \\
5 & $86-100 \%$ & Sangat baik \\
\hline
\end{tabular}

\section{TEMUAN DAN DISKUSI PENELITIAN}

\section{Temuan}

Penelitian ini bertujuan untuk meningkatkan keterampilan proses peserta didik dengan menerapkan model pembelajaran STS. Penelitian tindakan kelas ini dilaksanakan di kelas IV MI Al-Hanin yang berlangsung dalam dua siklus, masing- masing siklus dilaksanakan sebanyak dua kali pertemuan. Pelaksanaan penelitian dilakukan selama tiga minggu.

Setiap pertemuan membahas materi yang berbeda namun masih dalam KD yang sama yakni 3.7 Menerapkan sifat-sifat cahaya dan keterkaitannya dengan indera penglihatan. 4.7 Menyajikan laporan hasil pengamatan dan/atau percobaan yang memanfaatkan sifat-sifat cahaya. Siklus I pertemuan pertama membahas tentang cahaya dapat diuraikan melalui percobaan membuat caram warna dan siklus I pertemuan kedua membahas tentang sifat cahaya dapat merambat lurus dan dapat menembus benda bening melalui percobaan membuat proyektor sederhana. Sedangkan, pada siklusi II pertemuan ketiga membahas tentang sifat cahaya dapat dipantulkan dengan mambuat alat optik yaitu periskop sederhana dan siklus II pertemuan keempat juga membahas sifat cahaya dapat dipantulkan melalui pembuatan kaleidoskop sederhana.

Hasil penelitian berupa non tes. Data hasil non tes berupa lembar pengamatan keterampilan proses, aktivitas guru dan aktivitas peserta didik. Rangkaian kegiatan tiap siklus dalam penelitian tindakan kelas terdiri dari perencanaan, pelaksanaan, pengamatan, dan refleksi. 


\section{Pelaksanaan Tindakan}

\section{Siklus I Pertemuan I}

Pertemuan pertama sikus I dilaksanakan pada hari Senin tanggal 14 Januari 2019 membahas tentang subtema 2 yaitu Pahlawanku Kebanggaanku, pembelajaran pertama terdiri dari pelajaran Bahasa Indonesia, IPS dan IPA. Pembelajaran Bahasa Indonesia dan IPS dibahas pada jam pelajaran kedua sampai keempat dengan waktu 3x35 menit. Sedangkan pembelajaran IPA yang dilaksanakan pada jam pelajaran kelima sampai keenam dengan waktu 2x35 menit. Pelaksanaan pembelajaran IPA pada pertemuan pertama siklus I dilakukan berdasarkan rencana pelaksanaan pembelajaran yang telah dipersiapkan dan berpedoman pada silabus dan kurikulum. Materi yang dibahas adalah membuat cakram warna untuk membuktikan sifat cahaya dapat diuraikan menjadi 7 warna (merah, jingga, kuning, hijau, biru, nila dan ungu).

Pada kegiatan awal sebelum pembelajaran dimulai, guru membuka pelajaran dengan mengucapkan salam dilanjutkan dengan berdoa kemudian guru memberi motivasi dan mengkondisikan kelas supaya peserta didik siap untuk belajar. Guru memberikan apersepsi yakni mengaitkan materi IPA dengan materi pada pembelajaran sebelumnya "apakah yang kamu tahu tentang cahaya, apakah cahaya hanya dihasilkan oleh senter?". kemudian beberapa peserta didik berkomentar dengan jawaban yang beragam. Kemudian guru menjelasakan langkah-langkah pembelajaran STS serta menjelaskan tujuan dan kompetensi yang ingin dicapai.

Pada kegiatan inti, guru membagi peserta didik menjadi 3 kelompok, masingmasing kelompok terdiri atas 4 orang. Guru meminta peserta didik untuk mengamati diagram cahaya yang ada di depan kelas. Diagram tersebut berisi 3 isu yang menunjukan bahwa cahaya dapat diuraikan yaitu : (1)Cahaya dapat dilihat oleh indera peraba, (2)Pelangi memiliki warna-warna yang beragam, warna pelangi tersebut dapat diuraikan menjadi 7 warna yang berbeda, (3)Sumber cahaya terbesar di bumi adalah lampu PLN. Guru memberikan satu stiker cahaya kepada setiap kelompok. Guru memberikan waktu dua menit kepada tiap kelompok untuk melakukan diskusi singkat untuk memilih yang mana diantara diagram tersebut yang merupakan isu tentang sifat cahaya.

Perwakilan kelompok diminta maju ke depan dan menempelkan stikernya. Guru memberikan kesempatan kepada masing-masing kelompok untuk mengomentari atau menyanggah jawaban dari kelompok lain. Guru menjelaskan percobaan yang harus dikerjakan setiap kelompok serta membagikan LKS kepada setiap peserta didik. Setiap kelompok diminta untuk menyiapkan alat dan bahan yang sudah dibawa dari rumah dan ditugaskan untuk melakukan langkah-langkah percobaan sesuai dengan LKS, guna membuktikan bahwa cahaya dapat diuraikan. Setiap peserta didik dalam kelompok saling bekerja sama untuk membuat cakram warna. Guru memberikan penekanan konsep kunci kepada peserta didik. Kemudian guru memberikan reward pada kelompok yang 
melakukan percobaan dengan baik. Setelah selesai guru meminta peserta didik untuk menjawab soal uraian keterampilan proses yang ada pada LKS, kemudian guru mengajak peserta didik untuk menyimpulkan materi yang ditelah dipelajari hari ini dan menutup kelas dengan ucapan salam.

\section{Siklus I pertemuan II}

Pertemuan kedua sikus II dilaksanakan pada hari Rabu tanggal 16 Januari 2019 membahas tentang subtema 2 pembelajaran ketiga yang terdiri atas pelajaran bahasa Indonesia, PJOK dan IPA. Pembelajaran bahasa Indonesia dan PJOK dibahas pada jam pelajaran kedua sampai ketiga dengan waktu 2x35 menit. Sedangkan pembelajaran IPA yang dilaksanakan pada jam pelajaran keempat sampai keenam dengan waktu 3x35 menit. Materi yang dibahas adalah membuat membuktikan sifat cahaya dapat menembus benda bening dan merambat lurus pada proyektor sederhana.

Pada kegiatan awal sebelum pembelajaran dimulai, guru membuka pelajaran dengan mengucapkan salam dilanjutkan dengan berdoa kemudian guru memberi motivasi dan mengkondisikan kelas supaya pembelajaran menjadi lancar. Setelah melakukan apersepsi guru memberikan pertanyaan yang berkaitan dengan materi yang akan dibahas. "apakah kalian pernah menonton film di bioskop? Tahukah kalian apakah alat yang digunakan sehingga mampu menampilkan gambar dengan layar yang besar?” beberapa peserta didik memberikan pendapatnya.

Pada kegiatan inti sama dengan pertemuan I Guru membagi peserta didik menjadi 3 kelompok dan menyajikan 4 isu yang berkenaan dengan sifat cahaya dapat menembus benda bening dan cahaya dapat merambat lurus yaitu: (1)Cahaya senter dapat menembus tembok, (2) Cahaya dapat menembus gelas kaca, (3) Cahaya akan memantul bila di arahkan pada kain berwarna hitam, (4) Cahaya lampu senter akan merambat lurus pada jajaran papan yang dilubangi bagian tengahnya. Guru memberikan dua stiker cahaya kepada setiap kelompok. Guru menunjuk perwakilan setiap kelompok untuk maju kedepan yaitu peserta didik yang wajahnya terlihat paling mengantuk. Guru menjelaskan percobaan membuat proyektor sederhana yang akan dikerjakan setiap kelompok serta membagikan LKS kepada setiap peserta didik guna membuktikan bahwa cahaya memilki sifat yakni dapat menembus benda bening dan dapat merambat lurus. Guru memberikan penekanan konsep kunci kepada peserta didik Setiap peserta didik dalam kelompok saling bekerja sama untuk membuat proyektor sederhana, kemudian menjawab soal dan diakhiri dengan kegiatan menyimpulkan.

\section{Siklus II pertemuan 3}

Pertemuan ketiga sikus II dilaksanakan pada hari Senin tanggal 21 Januari 2019 membahas tentang sutema 3 pembelajaran pertama yang terdiri atas pelajaran Bahasa Indonesia, IPS dan IPA. Pembelajaran Bahasa Indonesia dan IPS dibahas pada jam pelajaran kedua sampai keempat dengan waktu 3x35 menit. Sedangkan pembelajaran IPA 
yang dilaksanakan pada jam pelajaran kelima sampai keenam dengan waktu 2x35 menit. Materi yang dibahas adalah membuat periskop sederhana yang ada pada kapal selam untuk membuktikan bahwa periskop menggunakan sifat cahaya dapat dipantulkan.

Kegiatan awal diawali dengan berdoa dan mempersiapkan kelas serta melakukan apersepsi dilanjutkan dengan kegiatan inti dimana guru membagi peserta didik menjadi beberapa kelompok. Guru meminta peserta didik untuk mengamati diagram cahaya yang ada di depan kelas. Diagram tersebut berisi 3 buah gambar dengan deskripsi isu, salah satu dari ketiga isu tersebut adalah isu yang benar tentang cahaya dapat dipantulkan kemudian dilanjutkan dengan kegiatan tanya jawab dan guru memberikan penekanan konsep kunci kepada peserta didik kemudian melakukan percobaan membuat periskop untuk membuktikan bahwa periskop menggunakan sifat cahaya yaitu cahaya dapat dipantulkan.

Kegiatan akhir dilaksanakan selama \pm 5 menit. Guru bertanya kepada peserta didik mengenai apa yang mereka pelajari hari ini kemudian guru memberikan kesempatan kepada peserta didik untuk bertanya. Guru bersama peserta didik menyimpulkan materi pembelajaran Guru memberi tahu peserta didik materi yang akan dipelajari pada pertemuan selanjutnya dan meminta peserta didik untuk membawa alat dan bahan untuk percobaan membuat kaleidoskop serta mengerjakan soal latihan yang tertera di LKS. Guru menutup pelajaran dengan mengucapkan hamdalah dan salam.

\section{Siklus II pertemuan 4}

Pertemuan keempat sikus II dilaksanakan pada hari Jumat tanggal 25 Januari 2019 membahas tentang subtema 3 pembelajaran ketiga yang terdiri atas pelajaran Bahasa Indonesia, PJOK dan IPA. Materi yang dibahas adalah membuktikan sifat cahaya dapat dipantulkan pada pada kaleidoskop sederhana. Peneliti sebagai guru dan guru kelas IV serta teman sejawat bertindak sebagai observer.

Kegiatan awal guru mempersiapkan kelas dan diawali dengan membaca doa bersama-sama kemudian guru menanyakan materi yang telah lalu pada Kegiatan inti dilaksanakan selama \pm 85 menit. Guru meminta peserta didik untuk mengamati diagram cahaya yang ada di depan kelas. Diagram tersebut berisi 3 buah isu yang di bahas bersamasama. Guru memberikan penekanan konsep kunci kepada peserta didik. Guru menjelaskan percobaan membuat kaleidoskop sederhana yang akan dikerjakan setiap kelompok serta membagikan LKS kepada setiap peserta didik. Setiap kelompok diminta untuk menyiapkan alat dan bahan yang sudah dibawa dari rumah dan ditugaskan untuk melakukan langkah-langkah percobaan sesuai dengan LKS, guna membuktikan bahwa cahaya memilki sifat yakni cahaya dapat dipantulkan. Kemudian guru memberikan konsep kunci pada peserta didik dilanjutkan dengan mengerjakan soal yang sudah disediakan oleh guru dan ditutup dengan membuat kesimpulan bersama. 


\section{DISKUSI}

\section{Aktivitas Guru}

Aktivitas guru dengan menggunakan model pembelajaran STS pada siklus I masih terdapat beberapa kekurangan diantaranya guru menggunakan bahasa yang kurang komunikatif pada saat mengembangkan isu sehingga peserta didik sulit, memahami isu yang dimaksud, kurangnya management waktu membuat peserta didik terburu-buru saat mengerjakan tes tertulis dan penggunaan bahasa yang tidak sesuai dengan taraf lingusitik peserta didik. Setelah diadakan perbaikan seperti guru menggunakan deskripsi cerita pada saat menyampaikan isu dan guru menggunakan pilihan kata yang sesuai dengan taraf bahasa peserta didik.

Setelah diadakan perbaikan pada siklus II model pembelajaran Sceince Technology and Society aktivitas guru dapat meningkat, menurut Sitiatava Rizema Putra dengan model pembelajaran ini guru dapat memadukan berbagai metode dan guru mempunyai pandangan yang luas tentang sains. Sains menyadarkan guru bahwa tidak selamanya guru berfungsi sebagai informan. Artinya pada pembelajaran ini guru hanya berperan sebagai fasilitator yang membantu peserta didik menemukan konsep pembelajaran lewat sebuah penyajian isu dan diselesaikan dengan percobaan ilmiah. Diketahui bahwa pada siklus I (pertemuan pertama dan kedua) aktivitas guru tergolong baik, dengan persentase $70 \%$. Pada siklus II (pertemuan ketiga dan keempat) meningkat menjadi 90\% tergolong baik. Persentase akhir aktivitas guru yaitu 90\% terkatagori baik sehingga dapat dikatakan bahwa aktivitas guru telah sesuai dengan langakah-langkah pada model pembelajaran STS dan mampu meningkatkan keterampilan proses. Lebih jelas dapat dilihat pada tabel 1.

\section{Aktivitas Peserta Didik}

Aktivitas peserta didik selama kegiatan belajar mengajar dengan model pembelajaran STS pada pertemuan pertama di siklus I, persentase aktivitas peserta didik secara klasikal diperoleh 65\% dengan kategori cukup tinggi hal ini terjadi karena peserta didik belum terbiasa belajar menggunakan model pembelajaran dimana peserta didik diajak untuk mengupas suatu isu kemudian langsung menyelesaikan atau mencari solusi atas isu tersebut menggunakan percobaan ilmiah. Pada pertemuan kedua di siklus I persentase aktivitas peserta didik yakni 72,08\% dengan kategori cukup tinggi. Sedangkan pada pertemuan ketiga di siklus II terjadi peningkatan $80 \%$ dengan kategori tinggi. Pada pertemuan keempat di siklus II persentase mencapai 85,83\% dengan kategori tinggi. Setelah pertemuan keempat peserta didik sudah terbiasa dengan model pembelajaran ini, sehingga dari tahap awal yaitu tahap mengemukakan isu sampai tahap akhir yaitu tahap penilaian yang terdiri dari cara belajar yang mencakup ranah kognnitif dan psikomotor sudah mengalami perkembangan yang signifikan. Hal ini sesuai dengan kelebihan dari model pembelajaran STS yang di kemukakan oleh Sitiatava Rizema Putra bahwa model 
ini menekankan cara belajar yang baik, yaang mencakup ranah kognitif, afektif dan psikomotor. Agar lebih jelas peningkatan aktivitas peserta didik dapat dilihat pada tabel 2.

Tabel 1 Rekapitulasi Hasil Observasi Aktivitas Guru Pada Siklus I Dan Siklus II

\begin{tabular}{|c|c|c|c|c|c|c|c|}
\hline \multirow[b]{2}{*}{ No } & \multirow[b]{2}{*}{ Aktivitas yang diamati } & \multicolumn{2}{|c|}{ Siklus I } & \multicolumn{4}{|c|}{ Siklus II } \\
\hline & & $\begin{array}{l}\text { Skor } \\
\text { pert } 1\end{array}$ & $\begin{array}{l}\text { Skor } \\
\text { pert } 2\end{array}$ & Jumlah & $\begin{array}{l}\text { Skor } \\
\text { pert } 3\end{array}$ & $\begin{array}{l}\text { Skor } \\
\text { pert } 4\end{array}$ & Jumlah \\
\hline 1. & $\begin{array}{l}\text { Guru mengemukakan } \\
\text { isu-isu yang berkembang } \\
\text { di masyarakat sesuai } \\
\text { dengan materi }\end{array}$ & 3 & 3 & 6 & 4 & 4 & 8 \\
\hline 2. & $\begin{array}{lr}\text { Guru } & \text { melakukan } \\
\text { pembentukan } & \text { konsep } \\
\text { melalui metode seperti } \\
\text { metode demonstrasi, } \\
\text { pengamatan } \\
\text { eksperimen. }\end{array}$ & 3 & 3 & 6 & 4 & 4 & 8 \\
\hline 3. & $\begin{array}{l}\text { Guru meminta peserta } \\
\text { didik untuk } \\
\text { mengkomunikasikan } \\
\text { konsep-konsep yang } \\
\text { telah di pahami dan } \\
\text { meminta peserta didik } \\
\text { untuk mengaplikasikan } \\
\text { dalam kehidupan sehari- } \\
\text { hari. }\end{array}$ & 2 & 3 & 5 & 3 & 4 & 7 \\
\hline 4. & $\begin{array}{lr}\text { Guru melakukan } \\
\text { pemantapan konsep } \\
\text { melalui penekanan pada } \\
\text { konsep-konsep kunci } \\
\text { yang penting dalam } \\
\text { bahan ajar. }\end{array}$ & 3 & 3 & 6 & 3 & 4 & 7 \\
\hline 5. & $\begin{array}{l}\text { Guru melakukan } \\
\text { penilaian terhadap } \\
\text { konsep-konsep yang } \\
\text { telah diajarkan melalui } \\
\text { tes tertulis dan tes lisan, } \\
\text { kinerja produk }\end{array}$ & 2 & 3 & 5 & 3 & 3 & 6 \\
\hline \multicolumn{2}{|c|}{ Jumlah } & 13 & 15 & 28 & 17 & 19 & 36 \\
\hline \multicolumn{2}{|c|}{ Persentase } & $65 \%$ & $75 \%$ & $70 \%$ & $85 \%$ & $95 \%$ & $90 \%$ \\
\hline \multicolumn{2}{|c|}{ Kategori } & $\begin{array}{l}\text { Cukup } \\
\text { Baik }\end{array}$ & $\begin{array}{l}\text { Cukup } \\
\text { Baik }\end{array}$ & $\begin{array}{l}\text { Cukup } \\
\text { Baik }\end{array}$ & Baik & Baik & Baik \\
\hline
\end{tabular}




\section{Tabel 2 Rekapitulasi Hasil Observasi Aktivitas Peserta Didik Siklus I dan Siklus II}

\begin{tabular}{|c|c|c|c|c|c|c|c|}
\hline \multirow[b]{2}{*}{ No } & \multirow[b]{2}{*}{ Aktivitas yang diamati } & \multicolumn{3}{|l|}{ Siklus I } & \multicolumn{3}{|c|}{ Siklus II } \\
\hline & & $\begin{array}{l}\text { Skor } \\
\text { pert } 1\end{array}$ & $\begin{array}{l}\text { Skor } \\
\text { pert } 2\end{array}$ & Jumlah & $\begin{array}{l}\text { Skor } \\
\text { pert } 3\end{array}$ & $\begin{array}{l}\text { Skor } \\
\text { pert } 4\end{array}$ & Jumlah \\
\hline 1. & $\begin{array}{l}\text { Peserta didik } \\
\text { mengemukakan } \\
\text { pengetahuan awalnya } \\
\text { tentang isu-isu yang telah } \\
\text { diberikan oleh guru. }\end{array}$ & 35 & 38 & 73 & 41 & 45 & 86 \\
\hline 2. & $\begin{array}{l}\text { Peserta didik diberi } \\
\text { kesempatan untuk } \\
\text { melakukan metode } \\
\text { tertentu agar dapat } \\
\text { menemukan konsep. }\end{array}$ & 29 & 33 & 62 & 38 & 40 & 78 \\
\hline 3. & $\begin{array}{l}\text { Peserta didik } \\
\text { mengkomunikasikan } \\
\text { konsep-konsep yang telah } \\
\text { dipahami dan mencoba } \\
\text { untuk mengaplikasikannya } \\
\text { dalam kehidupan sehari- } \\
\text { hari. }\end{array}$ & 30 & 34 & 64 & 34 & 39 & 73 \\
\hline 4. & $\begin{array}{l}\text { Peserta didik } \\
\text { menggunakan kata kunci } \\
\text { yang diberikan guru untuk } \\
\text { mematangkan konsep } \\
\text { yang didapat. }\end{array}$ & 28 & 31 & 59 & 37 & 39 & 76 \\
\hline 5. & $\begin{array}{l}\text { Peserta didik mengerjakan } \\
\text { soal evaluasi untuk } \\
\text { mengukur } \\
\text { kemampuan. }\end{array}$ & 34 & 37 & 71 & 42 & 43 & 85 \\
\hline Jum & & 156 & 173 & 329 & 192 & 206 & 398 \\
\hline Pers & entase & 65 & 72,08 & 68,54 & 80 & 85,83 & 82,91 \\
\hline Kate & gori & $\begin{array}{l}\text { Cukup } \\
\text { Tinggi }\end{array}$ & $\begin{array}{l}\text { Cukup } \\
\text { Tinggi }\end{array}$ & $\begin{array}{l}\text { Cukup } \\
\text { Tinggi }\end{array}$ & Tinggi & Tinggi & Tinggi \\
\hline
\end{tabular}


Aktivitas peserta didik dengan menggunakan model pembelajaran STS mengalami peningkatan. Pada siklus I (pertemuan pertama dan kedua) aktivitas peserta didik hanya mencapai 68,54\% pada siklus II (pertemuan ketiga dan keempat) meningkat menjadi $82,91 \%$.

\section{Keterampilan Proses}

Tabel 3 Rekapitulasi Keterampilan Proses Peserta Didik Pratindakan, Siklus I dan Siklus II

\begin{tabular}{lllllll}
\hline Sub Aspek & Pratindakan & Persentase & Siklus I & Persentase & Siklus II & Persentase \\
\hline Mengamati & 34 & 70,83 & 36,5 & 76,03 & 44 & 91,66 \\
Mengkomuniasikan & 21 & 43,75 & 29 & 60,36 & 39,50 & 82,29 \\
Mengklasifikasikan & 20 & 41,66 & 32 & 66,66 & 37 & 77,08 \\
Mengukur & 0 & 0 & 32,5 & 67,70 & 41 & 85,41 \\
Mempredisksikan & 19 & 39,58 & 30 & 62,50 & 38,50 & 80,20 \\
Menyimpulkan & 19 & 39,58 & 30 & 62,50 & 38,50 & 80,20 \\
Jumlah & 113 & 235,4 & 190 & $395.76 \%$ & 238,50 & 496,84 \\
Rata-rata & 22,6 & $\mathbf{4 7 , 0 8 \%}$ & 31,66 & $\mathbf{6 5 , 9 5 \%}$ & 39,75 & $\mathbf{8 2 , 8 0 \%}$ \\
\hline Kategori & & Kurang & $\mathbf{C u k u p}$ & & Baik \\
\hline
\end{tabular}

Berdasarkan tabel di atas diperoleh temuan : a) pada kondisi pratindakan rata-rata tingkat keterampilan proses peserta didik hanya mencapai 22,6. b) pada pembelajaran siklus 1 rata-rata tingkat keterampilan proses mencapai 31,66. Capaian ini menunjukkan mulai adanya peningkatan keterampilan sebesar 18,87\% (diperoleh dari selisih persentase keterampilan proses pratindakan dan siklus I) c) pada pembelajaran siklus 2, rata-rata keterampilan proses sains mencapai 39,75 data ini menunjukkan adanya peningkatan keterampilan proses sains peserta didik sebesar 16,85\% (diperoleh dari selisih persentase keterampilan proses siklus I dan siklus II).

Secara visualisasi rekapitulasi keterampilan proses peserta didik pratindakan, siklus I dan siklus II dapat diihat melalui grafik pada gambar 1. Data pada grafik keterampilan proses pada pratindakan, siklus I dan siklus II menggambarkan bahwa pada pratindakan memperoleh persentase 47,08\%, pada siklus I diperoleh persentase sebesar 65,95\%, dan pada siklus II memperoleh persentase $82,80 \%$. 


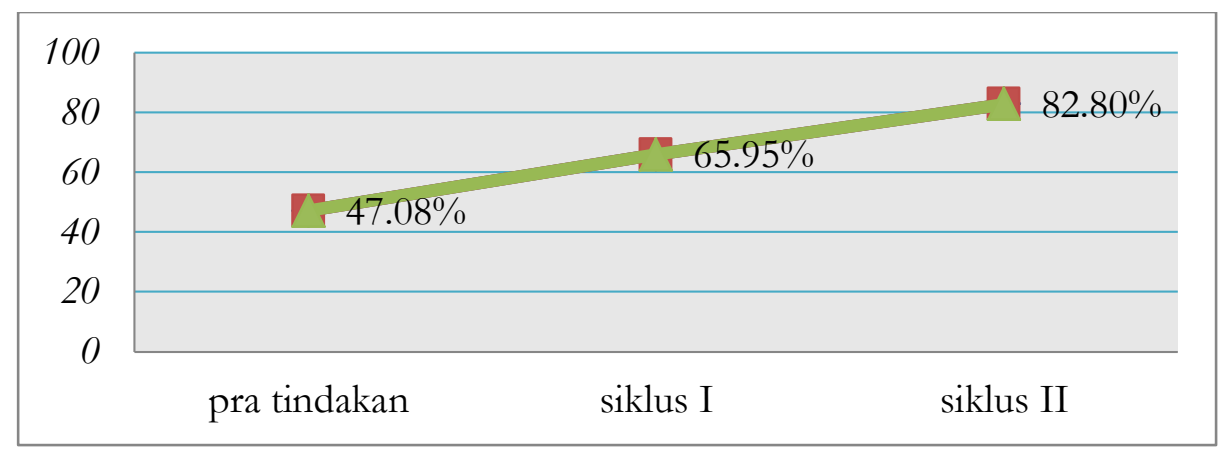

\section{Gambar 1 : Grafik keterampilan proses peserta didik dari pratindakan, siklus I, dan siklus II}

Temuan ini memperlihatkan adanya peningkatan tingkat keterampilan proses peserta didik. Persentase peningkatan ini adalah 18,87\% pada pembelajaran siklus I, dan 16,85\% pada pembelajaran siklus II. Temuan pada siklus I dan siklus II ini telah mencapai keberhasilan. Keberhasilan dari penelitian ini bermakna bahwa peserta didik mampu mengamati, mengkomunikasikan mengklasifikasikan, mengukur, memprediksikan dan menyimpulkan.

Hal ini menunjukkan bahwa model pembelajaran STS cukup efektif untuk meningkatkan keterampilan proses peserta didik, walaupun keterampilan proses yang dikuasai peserta didik belum mencapai kategori sangat baik. Model STS berhasil meningkatkan keterampilan proses peserta didik walaupun pada awalnya peserta didik agak kesulitan untuk mengikuti setiap kegiatan pembelajarannya. Namun dengan arahan dan bimbingan dari guru, maka peserta didik mulai belajar mengikuti tahapan model pembelajaran STS dengan baik. Dengan model pembelajaran ini peserta didik dapat belajar merancang suatu karya berdasarkan permasalahan yang muncul dalam pembelajaran. Peserta didik dituntut untuk aktif dan kreatif selama kegiatan berlangsung sehingga keterampilan proses peserta didik meningkat. Menurut Anna Poedjiadi (2010:132-133) alasan mengapa model STS perlu dikembangkan agar melatih keterampilan proses, karena dengan melatih keterampilan proses peserta didik diharapkan terbiasa merancang proses-proses yang perlu dilakukan untuk mencapai produk-produk ilmiah. Dalam kehidupan sehari-hari berarti ia akan selalu merencanakan langkah-langkah yang akan dilakukan untuk menyelesaikan masalah dengan berdaya guna dan hasil guna. Dengan demikian model STS efektif untuk meningkatkan keterampilan proses peserta didik.

Tujuan dari model pembelajaran STS adalah melibatkan peserta didik secara aktif dalam berfikir mengenai konsep pelajaran untuk mendorong peserta didik mencari sendiri konsep melalui proses-proses ilmiah sehingga menghasilkan produk ilmiah. Cara ini memberi kesempatan kepada peserta didik untuk berfikir secara analitis, untuk mengkolaborasikan sambil mereka membuat suatu produk ilmiah berdasarkan materi yang diajarkan. Dari situlah kemampuan peserta didik terlihat sehingga dapat meningkatkan 
keterampilan proses peserta didik. Selain membangun penguasaan materi, model ini betujuan melatih keterampilan proses pada pembelajaran IPA, karena dalam berlatih ini peserta didik dipacu untuk berpartisipasi secara aktif dan efisien dalam kinerjanya, menuntaskan hasil belajar peserta didik secara serentak, baik keterampilan produk, proses, maupun keterampilan kerjanya, menemukan dan membangun sendiri konsep serta dapat mendefenisikan secara benar untuk mencegah terjadinya miskonsepsi. Untuk memperdalam konsep, pengertian dan fakta yang dipelajarinya karena dengan latihan keterampilan proses, peserta didik sendiri berusaha mencari dan menemukan konsep tersebut. Kekurangan dalam penelitian ini yaitu : penggunaan waktu yang kurang efektif akan berdampak pada kurangnya penekanan konsep dan sedikitnya waktu untuk mengerjakan tes tertulis.

\section{KESIMPULAN}

Berdasarkan hasil penelitian dan pembahasan, dapat ditarik kesimpulan sebagai berikut. Model Pembelajaran STS dapat meningkatkan keterampilan proses. Adapun secara klasikal keterampilan proses IPA termasuk dalam kategori kurang (47,08\%) pada pratindakan kemudian meningkat menjadi kategori baik (82,80\%) pada siklus II. Penelitian berhenti pada siklus II karena rata-rata persentase keterampilan proses peserta didik secara individual pada siklus tersebut sudah mencapai 83,32\%. Dari temuan di atas maka dapat ditarik sebuah kesimpulan bahwa keterampilan proses peserta didik menggunakan Model Pembelajaran STS sudah berhasil karena $80 \%$ peserta didik baik secara individual dan klasikal sudah mampu melakukan: (1)Peserta didik dapat memberikan tanggapan setelah mengamati suatu objek, (2) Peserta didik dapat mengklasifikasikan suatu objek dengan tepat sesuai kelompoknya, (3) Peserta didik dapat menceritakan hasil pengamatannya baik secara lisan maupun tulisan, (4) Peserta didik dapat menggunakan alat ukur tertentu dan melakukan pengukuran dengan akurat, (5) Peserta didik dapat membuat suatu hipotesis sederhana sesuai dengan fakta dan konsep yang tersedia, (6) Peserta didik dapat menarik sebuah simpulan atas keadaan yang terjadi.

\section{SARAN} berikut:

Berdasarkan kesimpulan di atas, maka penulis mengajukan beberapa saran sebagai

Model pembelajaran STS ini dapat digunakan pada mata pelajaran yang sifatnya memadukan konsep dengan percobaan-percobaan ilmiah, seperti mata pelajaran IPA. Kepada guru sekolah dasar agar dapat melaksanakan pembelajaran IPA dengan model pembelajaran STS apabila sesuai dengan materi yang diajarkan agar tercipta suasana belajar yang aktif dan peserta didik tidak merasa jenuh dalam mengikuti proses pembelajaran. Kepada kepala sekolah diharapkan dapat mendukung pelaksanaan pembelajaran IPA yang menggunakan model pembelajaran STS dengan memfasilitasi sarana dan prasarana pendukung pembelajaran. Peneliti lain perlu melakukan penelitian lebih lanjut yang lebih mendalam mengenai model pembelajaran STS untuk meningkatkan aspek-aspek yang lain; misalnya kreativitas, motivasi dan hasil belajar. 


\section{REFERENSI}

Arifin, Z. (2014). Penelitian Pendidikan Metode dan Paradigma Baru. Bandung: Alfabeta.

Arikunto, S. (2010). Prosedur Penelitian Suatu Tindakan Praktik. Jakarta: Raja Grafindo.

Dimyati \& Mudjiono. (2015). Belajar dan Mengajar. Jakarta: Rineka Cipta.

Djamarah, S.B. (2014). Guru dan Anak Didik dalam Interaksi Edukatif. Jakarta: Rineka Cipta.

Fatonah, S. \& Prasetyo, Z. K. (2014). Pembelajaran Sains, Yogyakarta: Penerbit Ombak.

Istarani \& Ridwan, M. (2014). 50 Tipe Pembelajaran Kooperatif, Medan. CV. Widia Persada, 2014.

Marizka. I. (2009). Meningkatkan Hasil Belajar Peserta didik melalui tecModel Pembelajaran Sains Teknologi Masyarakat STM pada Mata Pelajaran Biologi Peserta didik Kelas II MTS Muhammadiyah Siak Hulu Kabupaten Pelalawan. Pekanbaru: Unri.

Poedjiadji, A. (2010). Sains Teknologi Masyarakat (Model Pembelajaran Kontekstual Bermuatan Nilai). Bandung: Upi dan Remaja Rosdakarya.

Purwanto, N. (2013). Prinsip-prinsip dan Teknik Evaluasi Pengajaran. Bandung: Remaja Rosdakarya.

Putra, S.R. (2013). Desain Belajar Mengajar Kreatif Berbasis Sains. Yogyakarta: Diva Pres.

Rahayubi, H. (2012). Teori-teori Belajar dan Aplikasi Pembelajaran Motorik. Bandung: Nusa Media.

Riduwan. (2010). Belajar Mudah Penelitian untuk Guru-Karayawan dan Peneliti Pemula. Bandung: Alfabeta.

Sanjaya, W. (2010). Penelitian Tindakan Kelas. Jakarta: Kencana.

Santi, D. V. (2014). Peningkatan Keteranpilan Proses dan Hasil Belajar IPA Menggunakan Model Pembelajaran Sains, Teknologi, Masyarakat (STM) pada Peserta didik SDN 1 Kalinanas-Wonosegoro Scholaria. 4(3).

Sudijono, A. (2004). Pengantar Statistik Pendidikan. Jakarta: Grafindo Persada.

Susilawati. (2013). Pembelajaran IPA Madrasah Ibtidaiyah. Pekanbaru: Benteng Media .(2014). Hakikat Sains dalam Praktik Pembelajaran Sains di Sekolah Dasar. Pekanbaru: Lembaga Penelitian dan Pengabdian kepada Masyarakat UIN SUSKA Riau.

Trianto. (2012). Model Pembelajaran Terpadu. Jakarta: PT Bumi Aksara.

Wahidin. (2006). Metode Pendidikan Ilmu Pengetahuan Alam untuk Program D-II dan S1 PGSD/PGMI. Bandung: Sangga Buana. 